\title{
ІНФОРМАТИЗАЦІЯ ОСВІТИ
}

\section{INFORMATYZACJA EDUKACJI}

https://doi.org/10.28925/2226-3012.2021.108

УДК 37.018.43:616-036.21COVID-19]:17

\section{Марія Чікарькова}

ORCHID iD 0000-0001-9664-8132

доктор філософських наук, професор, професор кафедри філософії і культурології,

Чернівецький національний університет імені Юрія Федьковича,

вул. М. Коцюбинського, 2, 58001, Чернівці, Україна,

chikarkova@ukr.net

\section{ЕТИЧНІ АСПЕКТИ ДИСТАНЦІЙНОГО НАВЧАННЯ У ДОБУ ПАНДЕМІї COVID-19}

Статтю присвячено етичним проблемам дистанційного навчання як виклику, з яким стикнулася освіma nід час пандемії COVID-19. Автор розглядає морально-ціннісні аспекти дистаниійного навчання на різних рівнях — від проблем міжнародного характерудо індивідуальної комунікачії між викладачем та студентом. Коло проблем, що стосуються етичної складової дистанційного навчання, доволі широке: цифрова нерівність, цифрова грамотність, педагогічні взаємини між «цифровими аборигенами» та «цифровими іммігрантами», особливості використання цифрового матеріалу тощо. У статті акцентується, що цифровізачія освіти вимагає високого рівня відповідальності й довіри від усіх учасників навчального прочесу. Найважливішою умовою етичної поведінки є обізнаність з иифровим етикетом та дієвість штрафних санкцій при його порушенні чи заохочень за його дотримання: відповідність етичним стандартам є фундаментальною умовою успіху у форматі дистанційного навчання.

Ключові слова: иифровізачія освіти; етичні стандарти; дистанційне навчання; иифрові аборигени; иифрові іммігранти.

(c) Чікарькова Марія, 2021

Вступ. У нинішньому світі, охопленому пандемією COVID-19, дистанційна освіта стала не примхою, а необхідністю. Нинішне покоління сприймає цифрову освіту вже не просто як e-learning, але як u-learning (ubiquitous learning) - «всюдисущу освіту», яка створює «всюдисуще навчальне середовище, котре дозволяє будь-кому вчитися у будь-якому місці у будь-який час» (Yahua, p. 117). Дистанційна освіта - не просто один з видів електронного навчання (e-learning), але й невід'ємна частина концепції безперервного навчання.
Ця тема сьогодні у центрі уваги не лише самих освітян, але й наукової спільноти. За останні два роки з'явилося чимало розвідок, в яких розглядалися питання переваг і недоліків цифровізації освітнього процесу, етапи та конкретні методики його впровадження, модифікація ролі вчителя тощо. Утім, чомусь зазвичай залишаються поза увагою вкрай важливі етичні моменти, пов'язані $з$ дистанційним навчанням, хоча такого роду проблем постає дуже багато. І особливо актуалізувалися вони в епоху пандемії, коли численні країни (й Україна опинилася 
серед них) почали опановувати цифрові технології в авральному порядку, пришвидшеними темпами й часто-густо стихійно.

Згадана тематика лише спорадично привертала увагу науковців, причому мова тут йде лише про онлайн-формат, без врахування специфічного стану, в якому опинилася освіта під час пандемії. Ситуація виглядає парадоксально, оскільки західні дослідники ще понад п'ятнадцять років тому визначали етичний чинник як один $з$ найбільш критичних викликів в онлайн-навчанні й наполягали на взаємній етичній відповідальності студентів і викладачів одного перед одним (Zembylas, Vrasidas, 2005, р. 77). Більше того етика відзначалася як один з наріжних каменів дистанційного навчання, оскільки без взаємної довіри та поваги тут неможливо добитися успіху (Sharma, Demiray, 2009, p. 329).

Ще до епохи пандемії М. Фарахані у роботі «Ethics Principles in Distance Education» розглядав питання, чому етичні стандарти мають таке важливе значення для дистанційного навчання та навіть запропонував власну систему етичних принципів для цієї форми освіти, яка грунтується на зобов'язаннях щодо студента, ресурсів електронного навчання; професійних якостей викладача; етичних аспектів навчання (Farahani, 2012, р. 891-893). Проблема стала ще актуальнішою, коли освіта вимушена була вся перейти в онлайн-формат, без попередньої підготовки -технічної, психологічної й, очевидно, етичної.

Як часто зазначають науковці, моральні проблеми у форматі онлайн-навчання постають особливо гостро через нестачу комунікації «обличчям до обличчя» між викладачем та студентом (Chawdhry, 2017, p. 70; Coleman, 2012), тому випадків порушення етичного кодексу тут більше, ніж у традиційних класах.

Коли мова заходить про етичні аспекти онлайн-навчання, то зазвичай відзначають приблизно один і той само перелік проблем. Наприклад, типовою є робота В. Гончарової «Об этике в дистанционном образовании: вызовы и задачи», авторка якої називає наступні проблемні місця цієї форми освіти: цифрова грамотність, імідж учасників освітнього процесу, місце проведення навчальної конференції, правила діалогу дистанційної конференції (Гончарова, 2021). Утім, додамо, що дистанційна освіта не обмежується самою лише формою онлайнконференції, та й моральних дилем тут $€$ набагато більше. Нерідко фокусуються на різних аспектах академічної нечесності (плагіат, примарне авторство тощо) та способах iï розпізнавання й унеможливлення у дистанційному форматі навчання. Не заперечуючи, звісно, важливість й актуальність цієї проблематики та багатогранність феномену академічної доброчинності (див., напр.: Батечко, Михайліченко, с. 29), з нашого погляду морально-етичні аспекти дистанційної освіти не обмежуються лише колом цих питань, і порушення принципів академічної доброчесності як такої - тут лише верхівка айсберга.

Метою нашої статті $є$ розгляд основних параметрів етичного виміру дистанційного навчання у добу COVID-19. При цьому ми свідомо залишаємо поза фокусом нашої розвідки тему Netiquette - Інтернет-етикету, оскільки вона вже достатньо розроблена й не відноситься безпосередньо до дистанційного навчання, будучи у цілому частиною комунікації у Мережі. Ми ж зосередимося на тому фундаменті, який складає філософське підгрунтя сучасного освітнього процесу у дистанційному форматі.

Методологічною базою дослідження $\epsilon$ емпіричний метод спостереження, оскільки сьогоднішні реалії дають для цього величезний і різноманітний матеріал. До цього долучається аксіологічний підхід у дусі В. Дільтея, котрий стверджував, що цінності формуються у сфері культури (а освіта є однією з іiі складових) як ідеали безвідносно до дійсності. Ми також звертаємося до статистичного методу, який дозволяє продемонструвати актуальність обраної тематики.

Актуалізація етичної складової навчання при переході у дистанційний формат. Питання про функціональну роль етичних постулатів у сучасному навчанні виглядає повноважним і змістовним вже хоча б тому, що воно спрямовує нашу увагу до екзистенціальних засад педагогічного діалогу як основного шляху передачі знань наступним поколінням, причому тут найважливіше - особистість і значущість постаті самого педагога. Сучасний польський філософ Р. Годонь, наприклад, каже про це так: «Розгляд відносин між етикою та освітою може бути здійснений різними способами. Репертуар можливих підходів та перспектив у вивченні того, що пов'язує етику та освіту, настільки великий, наскільки дозволяє уява тих, хто зосереджується на цих стосунках. Напевно, жодна теорія не може повністю представити це багатство. Однак, незалежно від позиції, яку ми займаємо у цьому питанні, варто спробувати з'ясувати, чому це все усе ще викликає інтерес як у сфері повсякденної освітньої практики, так і в академічному дискурсі. У цьому контексті особливо 
перспективно поглянути на етику та освіту в перспективі філософської рефлексії, хоча тут наголос робиться не стільки на історико-філософських чи системних поясненнях, скільки на тому, що є справді проблематичним у людському досвіді. Я розглядаю питання про співвідношення етики та освіти як запрошення дослідити сутність людського досвіду, особливо того, хто навчається і дбаючи про його розвиток. Така орієнтація питання також $є$ спробою зрозуміти умови, в яких можна вловити неповторність та унікальність педагогічного досвіду» (Godoń, 2016, s. 89).

Отже, повноцінна освіта неможлива без урахування морально-ціннісних аспектів. I це постає як ще більш актуальне питання з огляду на перехід в онлайн-формат. За даними дослідження, проведеного у 2019му році Т. Алдосемані, 52 \% викладачів стикалися з етичними проблемами під час онлайннавчання (Aldosemani, 2019). Мова йде ще про до-ковідну епоху. Думається, якби подібне дослідження провести зараз, то цифра збільшилася би й сягнула майже $100 \%$ - адже мова йде не про окрему форму дистанційної освіти, a про одномоментний перехід усієї освіти в онлайн-формат. А це породило низку викликів (у тому числі етичних) - від рівня країни до окремого викладача (учня, студента).

Проблема цифрової нерівності та цифрової грамотності у розрізі етики. Почнемо з такої фундаментальної категорії, як цифрова нерівність. Це проблема, що невід'ємно пов'язана 3 цифровою грамотністю. Обидві ситуації мають багато етичних аспектів на багатьох щаблях. Насамперед потрібно відзначити, що рівень розвитку (доступу) до цифрових технологій (а без них неможливе дистанційне навчання) $\epsilon$ різним і для різних країн, і навіть в одній країні у різних регіонах. Це пов'язано і з територіальною (не)доступністю до Інтернету, і з фінансовими питаннями. Отже, перед викладачем конкретного закладу вищої освіти постає цілка низка питань етичного гатунку. Чи має він право знижувати оцінку студенту, якщо той 3 технічних причин не може виконати завдання? Не може його вчасно завантажити? Не може взагалі вийти на зв'язок (особливо під час модулю, контрольної роботи тощо)? І як розібратися, чи студент не симулює, удаючи, що в нього технічні проблеми?

Ситуація з COVID-19 виявила, що часто студенти, «цифрові аборигени», не вміють користуватися цифровими технологіями для навчання, звикнувши бачити в Інтернеті лише засіб розважальності. Відповідно, перед викладачем постає новий виклик - дати їм необхідні знання не лише зі свого предмету, але також і необхідні технічні навички: «Вони потребують бути навченими цим технологіям як люди, народжені у спільноті, потребують бути навченими, як розмовляти мовою або використовувати інструменти та знаряддя, що доступні у спільноті» (Ng, p. 1066). Але чи є такі навички у самих викладачів, які часто-густо не $є$ «цифровими аборигенами», а скоріше «цифровими іммігрантами»?

Є. Пірайнен та С. Почебут фіксують цей трагічний розрив, що утворився нині в середовищі викладачів, коли, окрім педагогічних навичок, вони мають бути ще й технічно освіченими: «з одного боку, сьогодні все частіше спеціалісти в області професійної етики використовують термін «цифровий етикет», з іншої - дуже багато творчих, готових працювати у сфері науки й освіти людей просто не здатні слідувати правилам «цифрового етикету», оскільки не володіють відповідними технологіями» (Пирайнен, Почебут, 2018, с. 50).

У цьому ж річищі висловлюється М. Пренскі, котрий ввів у 2001 р. терміни «цифрові аборигени» та «цифрові іммігранти». Він акцентує: викладачі, що є «цифровими іммігрантами», які розмовляють застарілою мовою до-цифрової епохи, вчать популяцію, що говорить кардинально іншою мовою (Prensky. Digital, p. 2). Це нова варіація конфлікту поколінь, який отримав такий специфічний вигляд.

Звісно, є різні типи викладачів, і хтось давно опанував технології не гірше за студентів, але, по суті, це все зазвичай відбувалося на рівні власних ініціатив. Утім, у карантинні часи від усіх без винятку викладачів почали вимагати цифрової грамотності на рівні не просто споживача, але й творця цифрового контенту. Утім, викладачі, більшість з яких є «цифровими іммігрантами», мають різний рівень обізнаності щодо онлайн-технологій, але для кожного $з$ них ситуація миттєвого переводу викладання в онлайн-формат виявилася викликом. Я. Валек і П. Сладек подають наступну класифікацію «цифрових іммігрантів»:

— «захоплені» (в оригіналі — «keen»): добре орієнтуються у цифрових технологіях та активно інтегрують їх у своє життя;

— «гнучкі» (flexible): достатньо орієнтуються в цифровій сфері та частково «впускають» іï у своє життя, але потребують додаткового часу та допомоги в опануванні цифрових навичок; 
- «невідрегульовані» (неузгоджені maladjusted): відторгають цифрові технології взагалі (Valek, Sladek, p. 1867).

Очевидно, що найбільше проблем виникало у третьої категорії, яка в умовах традиційного навчання могла обходитися без цифрового контенту, але і перша категорія теж змушена була швидко адаптуватися до нових умов: адже одна справа - вміти зробити пост у Facebook і завантажити відео на YouTube й інша - створювати цифровий контент з навчальних дисциплін, які викладаєш.

Ми цілковито поділяємо точку зору, що викладач цифрової ери повинен бути націлений не на відтворення, а на створення. «Новий викладач скоріше буде розробником навчального середовища для залучення студентів, ніж тим, хто відтворює підручник» (Kalantzic, p. 204). Це все правильно, але чи етично від викладача вимагати знань, яким ніхто його не вчив, які додатково не оплачуються (як і час, що витрачається на їх опанування)? У багатьох навчальних закладах у період карантину проводилися вебінари, на яких роз'яснювалися принципи створення цифрового продукту та пояснювалася специфіка дистанційного навчання, але це крапля у морі у порівнянні з тим океаном незнання, в якому плавала більшість 3 них. 3 іншого боку, ті, хто майже з перших днів почали демонструвати високу обізнаність у сфері цифрових технологій і застосовувати їх в освітньому середовищі, зазвичай не отримували жодних стимулів для інтенсифікації цих процесів у галузі своїх начальних дисциплін. Таким чином, складалася ситуація, в якій і ті викладачі, що нічого не знають про дигіталізацію навчання, i ті, що активно користуються їі можливостями, отримують однакову винагороду за свою працю. Це веде до демотивації тих, хто спочатку захоплено взявся за створення цифрового контенту.

Особливості використання дигітального матеріалу: етична складова. Ще один важливий етичний аспект дистанційної освіти використання дигітального матеріалу. 3 вищевказаних причин зрозуміло, чому у нас так мало $€$ авторського продукту на ринку освітніх послуг i чому він часто низької якості. Очевидно також, що навіть найталановитіший педагог не в змозі створювати освітній продукт з такою швидкістю, 3 якою йде навчальний процес. Відповідно, виникає спокуса брати чужі матеріали. Звісно, є спеціалізовані ресурси з відкритим доступом, але їх не так багато й вони навіть близько не задовольняють потреби сучасного педагога. На жаль, численні вітчизняні викладачі в умовах, коли, з одного боку, від них вимагається цифровий контент, а з іншого - немає можливості його створити самому, змушені вдаватися до плагіату. Іронія ситуації полягає у тому, що багато хто з них щиро вважає: якщо матеріал розміщений в Інтернеті - він вже $\epsilon$ загальнодоступним, i автор не буде мати нічого проти його використання іншими людьми. Виявляється, що питання академічної доброчесності виступають доволі туманними не лише для студентів, але й для викладачів. Отже, як педагог може навчити етичній поведінці, якщо сам змушений поводитися неетично? 3 іншого боку, дехто розуміє, що використовувати чужі матеріали без дозволу порушує принципи академічної доброчесності, але який залишається у викладача варіант, якщо йому, наприклад, потрібно протягом тижня завантажити в Moodle матеріали для кількох занять 35 або й більше навчальних дисциплін?

Звісно, не можна сказати, що нічого не робиться для ознайомлення усіх учасників освітнього процесу з принципами академічної доброчесності. Сьогодні багато закладів вищої освіти вже розробили різного роду положення про дотримання таких принципів - 3 прописаними «штрафними санкціями». Утім, зауважимо, що це насамперед стосується студентів, але викладачі теж можуть порушувати етичні норми. Крім того, з психології давно відомо, що краще працює система заохочень, ніж покарань. I важко не погодитися з тим, що учасники освітнього процесу краще б дотримувалися етичних стандартів, якби були натхненні діяти етично (Campbell, 2001, p. 402).

Очевидно також, що самої лише розробки різного роду положень недостатньо - як мінімум їх потрібно довести до свідомості всіх учасників освітнього процесу. Це цілком зрозуміло, і К. Келлі і К. Боннер називають необізнаність в етичних аспектах академічного спілкування (поряд $з$ лінощами та «тиском класу») однією з основних трьох причин ії порушення (Kelly, Bonner, 2005, p. 47). Інколи викладачі це не роблять, оскільки вважають, що усі ці принципи зрозумілі «за замовчуванням», але моніторинг студентських знань у різних університетах неодноразово доводив, що це не так. Ситуація ускладнюється ще й тим, що нині настала ера академічної мобільності, і нерідко навчальна група може складатися зі здобувачів вищої освіти з різних країн, де відповідно панують різні уявлення про (не)допустиме 
у навчальному процесі. Так, студенти з різних країн мають свої вподобання щодо використання програмного забезпечення (i, наприклад, сумновідомих торрентів) тощо. Навчальне середовище перестало бути гомогенним, і це потрібно враховувати.

Висновки. Отже, переведення навчання повністю у цифровий формат поставив цілу низку питань, на які поки що чіткої відповіді немає. Це не лише фундаментальні методологічні питання, але й питання етичні. Як перевірити, чи дотримується здобувач вищої освіти принципів академічної доброчесності? Як бути з викладачами, одні з яких швидко опановують технології, другі набагато повільніше? Якими мають бути методи заохочення (покарання) при неетичній поведінці під час онлайн-навчання? I перелік таких питань можна продовжувати.

Звісно, у кожного викладача $є$ вже свої напрацювання та способи боротьби 3 неетичною поведінкою під час дистанційного навчання: випадковий перелік тестових питань, різні варіанти для кожної аудиторії, використання тестів відкритого типу тощо. Але низка проблем пов'язана з фінансами (наприклад, розв'язання проблеми цифрової нерівності), i їх викладачі не можуть вирішити індивідуально. На нашу думку, викладачі, які створюють освітній контент зі своїх курсів, також мають отримувати заохочення - або фінансове, або принаймні у вигляді зменшення аудиторного навантаження, аби стимулювати такий вид роботи. Очевидно, що кожний заклад вищої освіти повинен розробити власний етичний кодекс проведення дистанційних занять, якого мають дотримуватися усі учасники освітнього процесу. Ефективним була би також організація курсів для опанування цифрових навичок і створення освітнього продукту, але знову ж таки - на все це потрібні фінанси та час. Також нагальною необхідністю стає введення окремого курсу (або принаймні декількох тем хоча у рамках «Вступу до спеціальності») для студентів першого року навчання, який давав би можливість навчитися елементарним цифровим навичкам роботи з Moodle, наприклад та ознайомити ïx з принципами академічної доброчесності конкретного університету й правилами дистанційного навчання. Але знову ж таки заклад вищої освіти, аби чомусь навчати студентів, спочатку має виробити загальну політику у сфері дистанційного навчання. Отже, питань постає поки що набагато більше, ніж відповідей.

Утім, проведене дослідження дозволяє однозначно стверджувати, що, по-перше, етична складова є фундаментальною запорукою успіху у дистанційному навчанні, по-друге - зараз не існує чітко розроблених схем і алгоритмів для такого типу навчання з урахуванням морально-ціннісних аспектів, по-третє - вирішальним чинником залишається особистість викладача і студента (адже проконтролювати всі аспекти у будь-якому разі нереально).

Подальші дослідження можуть бути спрямовані на виявлення та конкретизацію ефективних напрямів роботи, що сприяють збереженню морально-ціннісної константи та викладацької етики у нинішніх умовах пандемії.

\section{Список використаної літератури}

1. Батечко Н., Михайліченко М. Феномен академічної доброчесності в контексті синергії наукових підходів. Освітологія. 2019. № 8. С. 26-33. DOI: https://doi.org/10.28925/2226-3012.2019.8.2633

2. Гончарова В. Г. Об этике в дистанционном образовании: вызовы и задачи. Педагогические науки. 2021. Вып. 6 (108). Ч. 4. С. 69-73. DOI: https://doi.org/10.23670/IRJ.2021.108.6.109

3. Пирайнен Е. В., Почебут С. Н. Этический аспект использования информационных технологий в образовательном процессе. Дискурс. 2018. № 4. C. 45-51. DOI: https://doi.org/10.32603/24128562-2018-4-4-45-51

4. Aldoseman T. I. Towards Ethically Responsive Online Education: Variables and Strategies from Educators' Perspective. Journal of Education and Learning. 2020. Vol. 9. № 1. P. 79-86. DOI: https://doi. org/10.5539/jel.v9n1p79

5. Campbell E. Let It Be Done: Trying to Put Ethical Standards into Practice. Journal of Education Policy. 2001. № 16 (5). P. 395-411. DOI: https://doi.org/10.1080/02680930110071011

6. Chawdhry A. Evaluating Ethics in Distance Education Learning from a Students Point of View. Issues in Information Systems. 2017. Vol. 18. № 3. P. 69-77. DOI: https://doi.org/10.48009/3_iis_2017_69-77.

7. Coleman P. D. Ethics, Online Learning and Stakeholder Responsibility for a Code of Conduct in Higher Education. Kentucky Journal of Excellence in College Teaching and Learning. 2012. № 9. Retrieved from https://encompass.eku.edu/kjectl/vol9/iss1/3 (дата звернення: 25.09.2021) 
8. Farahani M. F. Ethics Principles in Distance Education. Procedia - Social and Behavioral Sciences. 2012. Vol. 46. P. 890-894. DOI: https://doi.org/10.1016/j.sbspro.2012.05.218

9. Godoń R. Etyka i kształcenie: o integralności doświadczenia pedagogicznego. Chowanna. 2016. T. 1 (46). S. 89-99.

10. Kalantzis M., Cope B. The Teacher as Designer: Pedagogy in the New Media Age. E-Learning and Digital Media. 2010. Vol. 7. № 3. P. 200-222. DOI: https://doi.org/10.2304/elea.2010.7.3.200

11. Kelly K. B., Bonner K. Digital test, distance education and academic dishonest: Faculty and administrator perceptions and responses. Journal of Asynchronous Learning Networks. 2005. № 9 (1). P. 43-53. DOI: http://dx.doi.org/10.24059/olj.v9i1.1801

12. Ng W. Can we teach digital natives digital literacy? Computers \& Education. 2012. № 59. P. 1066-1078. DOI: https://doi.org/10.1016/j.compedu.2012.04.016

13. Prensky M. Digital Natives, Digital Immigrants. On the Horizon. 2001. Vol. 9. № 5. P. 1-6. DOI: https://doi.org/10.1108/10748120110424816

14. Sharma R. C., Demiray U. Ethical Practices and Implications in Distance Education: Lessons Learned. Ethical Practices and Implications in Distance Learning / Ed. Sharma R. C., Demiray U. Hershey-New York: Information science reference, 2009. P. 328-332.

15. Valek J., Sladek P. Immersed into Digital World: Learning and Students' Perception. Procedia Social and Behavioral Sciences. 2012. № 69. P. 1866-1870. DOI: https://doi.org/10.1016/j.sbspro.2012.12.139

16. Yahya S., Ahmad E. A., Jalil R. A. The Definition and Characteristics of Ubiquitous Learning: a Discussion. International Journal of Education and Development using Information and Communication Technology (IJEDICT). 2010. Vol. 6. № 1. P. 117-127.

17. Zembylas M., Vrasidas C. Levinas and the 'inter-face': The ethical challenge of online education. Educational Theory. 2005. № 55 (1). C. 61-78. DOI: https://doi.org/10.1111/j.1741-5446.2005.0005a.x

\section{References}

Batechko, N., Mykhailichenko, M. (2019). Fenomen akademichnoi dobrochesnosti v konteksti synerhii naukovykh pidkhodiv [Academic integrity phenomenon in the context of scientific approaches synergy]. Osvitolohiia, 8, 26-33. https://doi.org/10.28925/2226-3012.2019.8.2633

Goncharova, V. G. (2021). Ob etike v distancionnom obrazovanii: vyzovy i zadachi [On ethics in distance education: challenges and objectives]. Pedagogicheskie nauki, 6 (108), 4, 69-73. https://doi. org/10.23670/IRJ.2021.108.6.109

Pirajnen, E. V., Pochebut, S. N. (2018). Eticheskij aspekt ispol'zovaniya informacionnyh tekhnologij v obrazovatel'nom processe [Ethical aspect of the use of information technologies in the educational process]. Diskurs, 4, 45-51. https://doi.org/10.32603/2412-8562-2018-4-4-45-51

Aldoseman, T. I. (2020). Towards Ethically Responsive Online Education: Variables and Strategies from Educators' Perspective Journal of Education and Learning, 9 (1), 79-86. https://doi. org/10.5539/jel.v9n1p79.

Campbell, E. (2001). Let It Be Done: Trying to Put Ethical Standards into Practice Journal of Education Policy, 16 (5), 395-411. https://doi.org/10.1080/02680930110071011

Chawdhry, A. (2017). Evaluating Ethics in Distance Education Learning from a Students Point of View. Issues in Information Systems, 18 (3), 69-77. https://doi.org/10.48009/3_iis_2017_69-77

Coleman, P. D. (2012). Ethics, Online Learning and Stakeholder Responsibility for a Code of Conduct in Higher Education. Kentucky Journal of Excellence in College Teaching and Learning, 9. https:// encompass.eku.edu/kjectl/vol9/iss1/3.

Farahani, M. F. (2012). Ethics Principles in Distance Education. Procedia - Social and Behavioral Sciences, 46, 890-894. https://doi.org/10.1016/j.sbspro.2012.05.218

Godoń, R. (2016). Etyka i kształcenie: o integralności doświadczenia pedagogicznego Chowanna, 1 (46), 89-99.

Kalantzis, M., Cope, B. (2010). The Teacher as Designer: Pedagogy in the New Media Age. E-Learning and Digital Media, 7 (3), 200-222. https://doi.org/10.2304/elea.2010.7.3.200

Kelly, K. B., Bonner, K. (2005). Digital test, distance education and academic dishonest: Faculty and administrator perceptions and responses. Journal of Asynchronous Learning Networks, 9 (1), 43-53. http://dx.doi.org/10.24059/olj.v9i1.1801 
Ng, W. (2012). Can we teach digital natives digital literacy? Computers \& Education, 59, 1066-1078. https:// doi.org/10.1016/j.compedu.2012.04.016

Prensky, M. (2001). Digital Natives, Digital Immigrants. On the Horizon, 9 (5), 1-6. https://doi. org/10.1108/10748120110424816

Sharma, R. C., Demiray, U. (2009). Ethical Practices and Implications in Distance Education: Lessons Learned. In R. C. Sharma, U. Demiray (Eds), Ethical Practices and Implications in Distance Learning (pp. 328-332). Information science reference.

Valek, J., Sladek, P. (2012). Immersed into Digital World: Learning and Students' Perception. Procedia Social and Behavioral Sciences, 69, 1866-1870. https://doi.org/10.1016/j.sbspro.2012.12.139

Yahya, S., Ahmad, E. A., Jalil, R. A. (2010). The Definition and Characteristics of Ubiquitous Learning: a Discussion. International Journal of Education and Development using Information and Communication Technology (IJEDICT), 6 (1), 117-127.

Zembylas, M., Vrasidas, C. (2005). Levinas and the 'inter-face': The ethical challenge of online education. Educational Theory, 55 (1), 61-78. https://doi.org/10.1111/j.1741-5446.2005.0005a.x

\title{
ETYCZNE ASPEKTY KSZTAŁCENIA NA ODLEGŁOŚĆ W DNIU PANDEMII COVID-19
}

\author{
Czikarkowa Maria \\ ORCHID iD 0000-0001-9664-8132 \\ Doktor nauk filozoficznych, Profesor, \\ Profesor Wydziału Filozofii i Kulturoznawstwa \\ Czerniowiecki Uniwersytet Narodowy im. Jurija Fedkowicza, \\ ul. M. Kotsyubynskoho, 2, 58001, Czerniowce, Ukraina \\ chikarkova@ukr.net
}

Artykuł koncentruje się na kwestiach etycznych nauczania na odległość jako wyzwania, przed jakim stanęła edukacja podczas pandemii COVID-19. Autorka rozważa moralne i wartościowe aspekty kształcenia na odległość na różnych poziomach - od problemów o charakterze międzynarodowym po indywidualną komunikację między nauczycielem a uczniem. Zakres zagadnień związanych z etycznym komponentem nauczania na odległość jest dość szeroki: nierówność cyfrowa, alfabetyzacja cyfrowa, pedagogiczny konflikt między "cyfrowymi aborygenami"

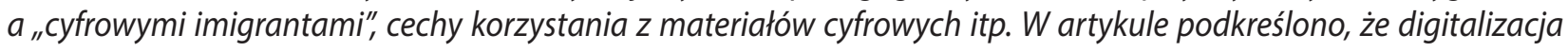
edukacji wymaga od wszystkich uczestników procesu edukacyjnego wysokiego poziomu odpowiedzialności $i$ zaufania. Najważniejszym warunkiem zachowania etycznego jest świadomość etykiety cyfrowej i skuteczność kar za jej łamanie lub zachęty do jej przestrzegania: przestrzeganie standardów etycznych jest podstawowym warunkiem sukcesu w formie kształcenia na odległość.

Słowa kluczowe: digitalizacja edukacji; standardy etyczne; kształcenie na odległość; cyfrowi aborygeni; cyfrowi imigranci.

\section{ETHICAL ASPECTS OF DISTANCE EDUCATION IN THE EPOCH OF THE COVID-19 PANDEMIC}

\author{
Chikarkova Maria \\ ORCHID iD 0000-0001-9664-8132 \\ Doctor of Philosophy, Professor, \\ Professor of Philosophy and Cultural Studies \\ Chernivtsi National University named after Yuri Fedkovych, \\ street M. Kotsyubynskoho, 2, 58001, Chernivtsi, Ukraine \\ chikarkova@ukr.net
}

The article focuses on the ethical issues of distance learning as a challenge faced by education during the COVID-19 pandemic. The author considers the moral and value aspects of distance learning at different levels - from problems 
of an international nature to individual communication between teacher and student. The range of problems related to the ethical component of distance learning is quite wide: digital inequality, digital literacy, pedagogical relations between "digital aborigines" and "digital immigrants", features of the use of digital material, etc. The author demonstrates the ambiguity of the problems that arose in the era of the pandemic. Thus, on the one hand, distance education requires a complete transition to digital format, on the other - both sides of the educational process are not ready for this format, because they do not have the necessary technical knowledge. Ethical issues are often financially related, such as addressing digital inequality or digital literacy.

The article emphasizes that the digitalization of education requires a high level of responsibility and trust from all participants in the educational process. The most important condition of ethical behavior is awareness of digital etiquette and the effectiveness of penalties for its violation or incentives for its observance: compliance with ethical standards is a fundamental condition for success in the format of distance learning. At the same time, this requires first of all the development of distance learning principles and a corresponding code of ethics at the level of a specific educational institution.

Keywords: digitalization of education; ethical standards; distance learning; digital aborigines; digital immigrants.

Стаття надійшла до редакиії 27.09.2021

Прийнято до друку 28.10.2021 